\title{
Kondisi Tenaga Kerja Penyandang Disabilitas : Tantangan Dalam Mewujudkan Sustainable Development Goals
}

\author{
Winsherly Tan \\ Fakultas Hukum Universitas Internasional Batam \\ winsherly@uib.ac.id \\ Submit: 02-10-2020; Review: 01-06-2021; Terbit: 10-06-20121
}

\begin{abstract}
Sustainable development or commonly called Sustainable Development Goals (SDGs) is a goal achieved by many countries, including Indonesia. One of the goals of the SDGs is to create jobs for all parties without exception. Then the principle used in the SDGs is "no one leaves". This is a challenge for the Indonesian state to create jobs for all, including people with disabilities. However, the data shows that the workforce for people with disabilities is still low. The purpose of this research is to analyze the implementation of the right to work for persons with disabilities in Indonesia. The research method used in this research is normative juridical. The type of data used is secondary data which consists of primary legal material, namely the 1945 Constitution and Law Number 8 of 2016 concerning Persons with Disabilities and uses the Law Effectiveness Theory from Soerjono Soekanto. The results of this study indicate that the implementation of the fulfillment of the right to work for persons with disabilities has increased quite well from 2016 to 2020, but it is still not optimal and effective due to several factors, including legal factors, law enforcement, society and culture.
\end{abstract}

\section{Keywords: SDGs, Disabilities, Rights to Work.}

\begin{abstract}
Abstrak
Pembangunan berkelanjutan atau biasa disebut dengan Sustainable Development Goals (SDGs) merupakan tujuan yang hendak dicapai oleh banyak negara termasuk Indonesia. Salah satu tujuan dari SDGs adalah untuk menciptakan lapangan pekerjaan bagi semua pihak tanpa terkecuali. Kemudian prinsip yang digunakan dalam SDGs adalah "no one leave behind". Hal ini menjadi tantangan bagi negara Indonesia untuk menciptakan lapangan pekerjaan untuk semua termasuk kaum penyandang disabilitas. Namun, data menunjukkan bahwa angka tenaga kerja penyandang disabilitas masih tergolong rendah. Tujuan penelitian ini adalah menganalisis pelaksanaan pemenuhan hak bekerja bagi penyandang disabilitas di Indonesia. Metode Penelitian yang digunakan dalam penelitian ini adalah yuridis normatif. Jenis data yang digunakan adalah data sekunder yang terdiri dari bahan hukum primer yaitu Undang-Undang Dasar 1945 dan Undang-Undang Nomor 8 Tahun 2016 Tentang Penyandang Disabilitas serta menggunakan Teori Efektivitas Hukum dari Soerjono Soekanto.
\end{abstract}


Hasil penelitian ini menunjukkan bahwa pelaksanaan pemenuhan hak bekerja bagi penyandang disabilitas mengalami peningkatan yang cukup baik dari tahun 2016 hingga 2020, namun tetap belum maksimal dan efektif dikarenakan beberapa faktor yaitu baik dari faktor hukum, penegak hukum, masyarakat dan kebudayaan.

Kata Kunci: SDGs, Disabilitas, Hak Bekerja.

\section{Pendahuluan}

Pada September 2000 telah dikeluarkannya sebuah deklarasi yang dikenal dengan The Millenium Development Goals (MDG's) yang diikuti oleh 189 negara yang dimana salah satu target dari deklrasi ini adalah untuk mengurangi jumlah penduduk miskin hingga 50\% pada tahun 2015. Kemudian, setelah berakhirnya era MDGs yang berhasil mengurangi penduduk miskin dunia hampir setengahnya (Ishartono, 2016). Di Indonesia, pelaksanaan MDGs telah memberikan perubahan yang positif. Walaupun masih ada beberapa target MDGs yang masih diperlukan kerja keras untuk mencapainya, tetapi sudah banyak target yang telah menunjukan kemajuan yang signifikan bahkan telah tercapai. Indonesia berhasil menurunkan proporsi penduduk dengan pendapatan kurang dari US\$ 1,00 (PPP) per kapita per hari dari 20,60 persen pada tahun 1990 menjadi 5,90 persen pada tahun 2008. Pemerintah juga telah berhasil menurunkan ketimpangan gender di tingkat pendidikan lanjutan. Hal ini dapat dilihat dari penurunan yang signifikan pada indikator rasio APM perempuan terhadap laki-laki SMA/MA/Paket $C$ dari 93,67 persen ada tahun 1993 menjadi 101,40 persen pada tahun 2011. Selain itu, angka kejadian tuberkulosis di Indonesia sudah berhasil mencapai target MDGs yaitu dari 343 pada tahun 1990 menjadi 189 kasus per 100.000 penduduk pada tahun 2011 (BPS, 2014).

Selanjutnya saat ini memasuki era SDGs (sustainable development goals), yang dimulai dengan pertemuan yang dilaksanakan pada tanggal 25-27 September 2015 di markas besar Perserikatan BangsaBangsa (PBB), New York, Amerika Serikat yang dihadiri perwakilan dari 193 negara. Suistainable Development Goals (SDG'S) adalah 
singkatan atau kepanjangan dari sustainable development goals, yaitu sebuah dokumen yang akan menjadi sebuah acuan dalam kerangka pembangunan dan perundingan negara-negara di dunia. Post-2015, juga dikenal sebagai Sustainabale Development Goals (SDGs) didefinisikan sebagai kerangka kerja untuk 15 tahun ke depan hingga tahun 2030. Berbeda dengan MDGs yang lebih bersifat birokratis dan teknokratis, penyusunan butir-butir SDGs lebih inklusif melibatkan banyak pihak termasuk organisasi masyarakat sipil atau Civil Society Organization (CSO). Penyusunan SDGs sendiri memiliki beberapa tantangan karena masih terdapat beberapa butir-butir target MDGs yang belum bisa dicapai dan harus diteruskan di dalam SDGs. Seluruh tujuan, target dan indikator dalam dokumen SDGs juga perlu mempertimbangkan perubahan situasi global saat ini (Wahyuningsih, 2017).

Tujuan SDGs antara lain : 1) Tanpa Kemiskinan, tidak ada kemiskinan dalam bentuk apapun di seluruh penjuru dunia. 2) Tanpa
Kelaparan, tidak ada lagi kelaparan, mencapai ketahanan pangan, perbaikan nutrisi, serta mendorong budidaya pertanian yang berkelanjutan. 3) Kesehatan yang Baik dan Kesejahteraan Menjamin kehidupan yang sehat serta mendorong kesejahteraan hidup untuk seluruh masyarakat di segala umur. 4) Pendidikan Berkualitas, Menjamin pemerataan pendidikan yang berkualitas dan meningkatkan kesempatan belajar untuk semua orang. 5) Kesetaraan Gender, mencapai kesetaraan gender dan memberdayakan kaum ibu dan perempuan. 6) Air Bersih dan Sanitasi, menjamin ketersediaan air bersih dan sanitasi yang berkelanjutan untuk semua orang. 7) Energi Bersih dan Terjangkau, menjamin akses terhadap sumber energi yang terjangkau, terpercaya, berkelanjutan dan modern untuk semua orang. 8) Pertumbuhan Ekonomi dan Pekerjaan yang Layak, mendukung perkembangan ekonomi yang berkelanjutan, lapangan kerja yang produktif serta pekerjaan yang layak untuk semua orang. 9) Industri, Inovasi dan Infrastruktur, 
membangun infrastruktur yang berkualitas, mendorong peningkatan industri yang berkelanjutan serta mendorong inovasi. 10) Mengurangi Kesenjangan, mengurangi

ketidaksetaraan baik di dalam sebuah negara maupun di antara negaranegara di dunia. 11)Keberlanjutan Kota dan Komunitas, membangun kota-kota serta pemukiman yang berkualitas, aman dan bekelanjutan.

12) Konsumsi dan Produksi Bertanggung Jawab, menjamin keberlangsungan konsumsi dan pola produksi.13) Aksi Terhadap Iklim, bertindak cepat untuk memerangi perubahan iklim dan dampaknya. 14) Kehidupan bawah laut, melestarikan dan menjaga keberlangsungan laut dan kehidupan sumber daya laut untuk perkembangan yang berkelanjutan.15) Kehidupan di Darat, melindungi, mengembalikan, dan meningkatkan keberlangsungan pemakaian ekosistem darat, mengelola hutan secara berkelanjutan, mengurangi tanah tandus serta tukar guling tanah. 16) Institusi Peradilan yang Kuat dan Kedamaian, meningkatkan perdamaian termasuk masyarakat untuk pembangunan berkelanjutan, menyediakan akses untuk keadilan bagi semua orang termasuk lembaga dan bertanggung jawab untuk seluruhkalangan. 17) Kemitraan untuk Mencapai Tujuan, Memperkuat implementasi dan menghidupkan kembali kemitraan global untuk pembangunan yang berkelanjutan.

Salah satu tujuan dari SDGs adalah meningkatkan pertumbuhan Ekonomi dan Pekerjaan yang Layak, mendukung perkembangan ekonomi yang berkelanjutan, lapangan kerja yang produktif serta pekerjaan yang layak untuk semua orang (tujuan kedelapan). Setiap manusia memiliki hak asasi yang sama. Hak manusia tidak dibedakan olehperbedaan fisik, warna kulit, ras, suku maupun kepercayaan yang dianutnya. Hak asasi manusia berlaku bagi seluruh orang di dunia. Begitu pula dengan penyandang disabilitas, mempunyai hak yang setara dengan orang lain (Geminastiti Purinami, 2018). Tujuan kedelapan dari SDGs ini menyatakan dengan tegas bahwa negara harus dapat menciptakan lapangan pekerjaan 
yang layak bagi semua orang tanpa terkecuali termasuk penyedian lapangan pekerjaan bagi kaum disabilitas.

Namun, berdasarkan data pada tahun 2016 dari Badan Pusat Statistik (BPS) menerbitkan Survey Ketenagakerjaan Nasional
(SAKERNAS) yang memungkinkan analisis yang lebih dalam tentang kondisi penyandang disabilitas di pasar tenaga kerja Indonesia. Estimasi jumlah penyandang disabilitas di Indonesia sebesar $12.15 \%$ dengan keterangan sebagai berikut:

Tabel 1. Kategori Penyandang Disabilitas

\begin{tabular}{cc}
\hline Katergori Sedang & Kategori Berat \\
\hline $10,29 \%$ & $1,87 \%$
\end{tabular}

Sumber: Badan Pusat Statistik (BPS)

Kemudian terkait dengan tingkat pendidikan penyandang disabilitas, jumlah penyandang disabilitas berdasarkan jenis kelamin terdiri dari $45,74 \%$ tidak pernah/tidak lulus SD, jauh dibandingkan non-penyandang disabilitas yang $\quad 87,31 \%$ berpendidikan SD ke atas.

Kemudian terkait dengan data penyandang disabilitas yang berada di pasar kerja Indonesia yaitu sebagai berikut:

Tabel 2. Data Partisipasi Penyandang Disabilitas di Pasar Kerja Indonesia

\begin{tabular}{|c|c|c|}
\hline No & Kategori Pekerja & Persentase \\
\hline 1 & Non- Penyandang Disabilitas & $70,40 \%$ \\
\hline 2 & Penyandang Disabilitas & $51,12 \%$ \\
\hline 3 & $\begin{array}{l}\text { Penyandang Disabilitas dengan kategori } \\
\text { berat }\end{array}$ & $20,27 \%$ \\
\hline
\end{tabular}

Sumber: Badan Pusat Statistik (BPS)

Kemudian, berikut adalah data terkait perbandingan sektor pekerjaan di formal dan informal, yaitu: 
Tabel 3. Perbandingan Pekerjaan pada Sektor Formal dan Informal

\begin{tabular}{|c|c|c|}
\hline No & Keterangan & Persentase \\
\hline 1 & $\begin{array}{l}\text { Dibandingkan dengan non penyandang } \\
\text { disabilitas }\end{array}$ & $49,17 \%$ \\
\hline 2 & $\begin{array}{l}\text { Pekerja penyandang disabilitas kebanyakan } \\
\text { bekerja di sektor informal }\end{array}$ & $65,54 \%$ \\
\hline 3 & $\begin{array}{l}\text { Pekerja informal untuk penyandang } \\
\text { disabilitas berat jauh lebih besar lagi }\end{array}$ & $75,8 \%$ \\
\hline
\end{tabular}

Sumber: Badan Pusat Statistik (BPS)

Oleh sebab itu, Indonesia mulai mengeluarkan sebuah regulasi dalam melindungi hak penyandang disabilitas, khususnya hak dalam memperoleh pekerjaan, yaitu Undang-Undang Nomor 8 Tahun 2016 tentang Penyandang Disabilitas. Pasal 3 menyatakan bahwa tujuan dari undang-undang ini yaitu: a. mewujudkan Penghormatan, pemajuan, Perlindungan, dan Pemenuhan hak asasi manusia serta kebebasan dasar Penyandang Disabilitas secara penuh dan setara; b. menjamin upaya Penghormatan, pemajuan, Perlindungan, dan Pemenuhan hak sebagai martabat yang melekat pada diri Penyandang Disabilitas; c. mewujudkan taraf kehidupan Penyandang Disabilitas yang lebih berkualitas, adil, sejahteralahir dan batin, mandiri, serta bermartabat; $d$. melindungi Penyandang Disabilitas dari penelantaran dan eksploitasi, pelecehan dan segala tindakan diskriminatif, serta pelanggaran hak asasi manusia; dan e. memastikan pelaksanaan upaya Penghormatan, pemajuan, Perlindungan, dan Pemenuhan hak Penyandang Disabilitas untuk mengembangkan diri serta mendayagunakan seluruh kemampuan sesuai bakat dan minat yangdimilikinya untuk menikmati, berperan serta berkontribusi secara optimal, aman,leluasa,dan bermartabat dalam segala aspek kehidupan berbangsa, bernegara,dan bermasyarakat.

Berdasarkan hal tersebut, maka terdapat satu rumusan masalah yang 
akan dikaji dalam penelitian ini yaitu bagaimana pemenuhan hak bekerja bagi penyandang disabilitas di Indonesia dalam hal mewujudkan tujuan kedelapan dari SDGs.

\section{Metode Penelitian}

Peneliti melaksanakan penelitian ini dengan metode penelitian yuridis normatif. Jenis data yang digunakan dalam penelitian ini yaitu data primer dan data sekunder. Data primer adalah data yang diperoleh dari website Badan Pusat Statistik, berita terkait dengan tenaga kerja penyandang

Sedangkan Data sekunder terdiri dari:

a) Bahan Hukum Primer

Sumber bahan hukum ini merupakan bahan-bahan hukum yang mempunyai kekuatan mengikat, yang dapat berupa norma dasar (Pancasila), peraturan dasar seperti Batang Tubuh Undang-Undang Dasar 1945, Peraturan Perundangundangan, Hukum yang tidak dikodifikasi, hukum adat, hukum Islam, yurisprudensi, traktar dan doktrin. Bahan hukum primer dalam penelitian ini adalah UUD 1945,
Undang-Undang Nomor 8 Tahun 2016 tentang Penyandang Disabilitas.

b) Bahan Hukum Sekunder.

Sumber bahan hukum ini yaitu bahan-bahan yang erat kaitannya dengan bahan hukum primer, dan dapat membantu menganalisis dan memahami bahan hukum primer, misalnya rancangan peraturan perundang-undangan, hasil karya ilmiah para sarjana, hasil-hasil penelitian, jurnal dan sebagainya. Dalam penelitian ini, bahan hukum sekunder meliputi Peraturan Hukum, Buku-buku, Jurnal Hukum, Makalah Hukum, serta Artikel Hukum.

c) Bahan Hukum Tersier

Sumber bahan hukum Tersier merupakan bahan hukum yang memberikan petunjuk maupun penjelasan terhadap bahan hukum primer dan sekunder; contohnya adalah kamus, indeks kumulatif, dan seterusnya (Soerjono Soekanto, 2009). Bahan hukum tersier yang terdapat dalam penelitian ini, yakni: Kamus Hukum dan Kamus Besar Bahasa Indonesia. 


\section{Hasil dan Pembahasan}

Data Tentang Tanaga Kerja Penyandang Disabilitas Tahun 2017

Berdasarkan data yang masuk ke sistem Kementerian Ketenagakerjaan bulan Agustus 2017, Menteri Ketenagakerjaan Muhammad Hanif Dhakiri menyatakan bahwa terdapat 440 perusahaan dengan jumlah tenaga kerja sekitar 237 ribu orang. Dari jumlah itu, tenaga kerja disabilitas yang terserap baru sekitar 2.851 orang atau sekitar 1,2 persen yang berhasil ditempatkan dalam sektor tenaga kerja formal. Berdasarkan data Sakernas pada Agustus 2017, penduduk usia kerja disabilitas nasional sebanyak 21,9 juta orang. Dari angka itu, sebanyak 10,8 juta disabilitas sudah bekerja (Tempo, 2017).

\section{Data Tentang Tanaga Kerja Penyandang Disabilitas Tahun 2019}

Berdasarkan data Kemenaker tahun 2019, jumlah tenaga kerja penyandang disabilitas di BUMN dan swasta mengalami peningkatan yakni sebanyak 4.537 pekerja pada 2018 dibanding tahun sebelumnya yang sebanyak 4.286 pekerja (Republika, 2020). Namun, catatan tersebut masih relatif jauh dari total penyandang disabilitas yang ada. Menurut data Badan Pusat Statistik (BPS) tahun 2019, jumlah penduduk usia kerja penyandang disabilitas tercatat sebesar 20,9 juta jiwa dan angkatan kerja penyandang disabilitas sebanyak 10,19 juta jiwa. Sementara jumlah penyandang disabilitas yang bekerja hanya 9,91 juta jiwa. Jumlah pengangguran terbuka dari penyandang disabilitas sebanyak 289 ribu orang. Berdasarkan data Kemenaker tahun 2019, jumlah tenaga kerja penyandang disabilitas di BUMN dan swasta terus mengalami peningkatan. Jika di tahun 2017 jumlah tenaga kerja difabel mencapai, 4.286 orang, angka tersebut naik di tahun 2018 menjadi 4.537 orang (BUMN, 2020).

\section{Pernyataan dari Kementerian Ketenagakerjaan}

Berdasarkan data dari BPS bulan Februari 2019 tercatat jumlah 
penduduk usia kerja penyandang disabilitas sebesar 20,9 juta orang. Dari angka tersebut, angkatan kerja terdata sebesar 10,19 juta dan yang bekerja 9,91 juta orang. Sementara itu, jumlah pengangguran terbuka untuk penyandang disabilitas tercatat sebesar 289 ribu orang. Menaker Ida Fauziyah mengatakan (Sindo News, 2021), penelitian menunjukkan tingkat partisipasi tenaga kerja tenaga disabilitas lebih rendah dibandingkan TPAK pekerja non disabilitas, dan upahnya relatif lebih rendah. Ada pula tingkat pengangguran terbuka yang lebih tinggi pada penyandang disabilitas berat. Pada tanggal 22 Juli 2020, Menteri Ketenagakerjaan dan Menteri Badan Usaha Milik Negara (BUMN) Erick Thohir menandatangani Nota Kesepahaman (MoU) tentang Pelatihan Kerja dan Penempatan Tenaga Kerja Penyandang Disabilitas Pada BUMN (AntaraNews, 2021). Menteri Ketenagakerjaan dan Menteri BUMN menyatakan bahwa semua BLK harus memberikan kesempatan kepada saudara-saudara penyandang disabilitas, kami juga memberdayakan tenaga kerja melalui beberapa program kewirausahaan sebagai bagian program perluasan kesempatan kerja. Kami berikan secara proporsional, termasuk program-program lainnya untuk memenuhi hak pekerja disabilitas.

\section{Pemenuhan Hak Bekerja Bagi Penyandang Disabilitas Di Indonesia Dalam Hal Mewujudkan Tujuan Kedelapan Dari SDGs.}

Sustanaible Development Goals atau biasa disebut dengan SDGs merupakan agenda yang disepakati pada bulan September 2015 di New York, Amerika Serikat. Kesepakatan tersebut menjadi titik sejarah baru dalam pembangunan global. SDGs disepakati dengan harapan dapat mengakomodasi masalah-masalah pembangunan secara lebih komprehensif. Baik secara kualitatif, maupun kuantitatif menargetkan penyelesaian tuntas terhadap setiap tujuan dan sasaranya. SDGs juga bersifat universal dan memberikan peran yang seimbang kepada seluruh negara baik negara maju, negara berkembang, dan negara kurang berkembang untuk berkontribusi 
penuh terhadap pembangunan, sehingga masing-masing negara memiliki peran dan tanggung jawab yang sama antara satu dengan yang lain dalam mencapai SDGs (Pupin, 2020).

SDGs membawa 5 prinsipprinsip mendasar yang menyeimbangkan dimensi ekonomi, sosial, dan lingkungan, yaitu 1) People (manusia), 2) Planet (bumi), 3) Prosperity (kemakmuran), 4) Peace (perdaiaman), dan 5) Partnership (kerjasama). Kelima prinsip dasar ini dikenal dengan istilah $5 \mathrm{P}$ dan menaungi 17 Tujuan dan 169 Sasaran yang tidak dapat dipisahkan, saling terhubung, dan terintegrasi satu sama lain guna mencapai kehidupan manusia yang lebih baik (Infid, 2020).

Kepala negara dan pemerintahan yang menyepakati SDGs telah meneguhkan komitmen bersama untuk menghapuskan kemiskinan, menghilangkan kelaparan, memperbaiki kualitas kesehatan, meningkatkan pendidikan, dan mengurangi ketimpangan. Agenda pembangunan ini juga menjanjikan semangat setiap orang dari semua golongan akan ikut melaksanakan dan merasakan manfaat SDGs, dengan memprioritaskan kelompokkelompok yang termarginalkan.

Semangat bahwa tidak ada seorang pun yang akan ditinggalkan (no one leave behind) memberikan sebuah tantangan besar untuk setiap kepala negara dalam mewujudkannya. Pada tujuan kedelapan SDGs dijelaskan bahwa pertumbuhan ekonomi dan pekerjaan yang layak, mendukung perkembangan ekonomi yang berkelanjutan, lapangan kerja yang produktif serta pekerjaan yang layak untuk semua orang. Pada tujuan kedelapan SDGs ini menyinggung tentang penyelenggaraan pekerjaan layak untuk semua orang. Hal ini merupakan salah satu wujud semangat SDGs yaitu no one leave behind. Penyelenggaraan lapangan kerja untuk semua tanpa terkecuali ini juga berlaku dan diperuntukkan bagi kaum penyandang disabilitas.

SDGs memiliki prinsip yang paling dasar yaitu "tidak ada seorang pun yang ditinggalkan". SDGs juga mengandung prinsip kesetaraan antar negara dan antar warga negara. 
SDGs tersebut diimplementasikan oleh Indonesia melalui 9 (Sembilan) agenda prioritas Presiden Joko Widodo (Nawacita) yang salah satunya adalah meningkatkan produktivitas rakyat dan daya saing di pasar internasional sehingga bangsa Indonesia bisa maju dan bangkit bersama bangsa-bangsa Asia lainnya (Winsherly Tan, 2020).

Dalam hal menciptakan lapangan pekerjaan dan atau menjamin hak bekerja bagi penyandang disabilitas. Indonesia, sebagai Negara yang bermartabat sangat menghormati, menghargai, memenuhi dan memberikan perlindungan bagi setiap warga negaranya tanpa kecuali. Hal ini tersurat dalam Pasal 5 ayat (1), Pasal 11, Pasal 20, dan Pasal 28 I ayat (2) UUD NRI Tahun 1945. Indonesia telah mengeluarkan regulasi yang secara eksplisit memberikan jaminan hak bekerja bagi penyandang disabilitas yaitu di Undang-Undang Nomor 8 Tahun 2016. Pada pasal 1 definisi "Penyandang Disabilitas" adalah setiap orang yang mengalami keterbatasan fisik, intelektual, mental, dan/atau sensorik dalam jangka waktu lama yang dalam berinteraksi dengan lingkungan dapat mengalami hambatan dan kesulitan untuk berpartisipasi secara penuh dan efektif dengan warga negara lainnya berdasarkan kesamaan hak.". Pasal 2 menyatakan bahwa "Pelaksanaan dan Pemenuhan hak Penyandang Disabilitas berasaskan: a.Penghormatan terhadap martabat; b.otonomi individu; c.tanpa Diskriminasi; d. partisipasi penuh; e.keragaman manusia dan kemanusiaan; f. Kesamaan Kesempatan; g. kesetaraan; h.Aksesibilitas; i.kapasitas yang terus berkembang dan identitas anak; j.inklusif; dan perlakuan khusus dan Perlindungan lebih." Kemudian pasal 5 menyebutkan bahwa salah satu hak dari penyandang disabilitas yaitu berhak mendapatkan pekerjaan.

Kemudian pasal 11 menyatakan bahwa: Hak pekerjaan, kewirausahaan, dan koperasi untuk Penyandang Disabilitas meliputi hak: a. memperoleh pekerjaan yang diselenggarakan oleh Pemerintah, Pemerintah Daerah, atau swasta tanpa Diskriminasi; b. memperoleh upah yang sama dengan tenaga kerja 
yang bukan Penyandang Disabilitas dalam jenis pekerjaan dan tanggungjawab yang sama; c. memperoleh Akomodasi yang Layak dalam pekerjaan; d. tidak diberhentikan karena alasan disabilitas; e. mendapatkan program kembali bekerja; f. penempatan kerja yang adil, proporsional, dan bermartabat; g. memperoleh kesempatan dalam mengembangkan jenjang karier serta segala hak normatif yang melekat di dalamnya; dan h.memajukan usaha, memiliki pekerjaan sendiri, wiraswasta, pengembangan koperasi, dan memulai usaha sendiri.

Konotasi masyarakat tentang penyandang disabilitas selalu negatif. Masyarakat sering menganggap penyandang disabilitas adalah orang yang memiliki penyakit sehingga dianggap tidak layak atau tidak dapat untuk bekerja (Hamidi, 2016).

Pemikiran kelompok yang konservatif adalah bahwa keadaan penyandang disabilitas merupakan sebuah kehendak Tuhan sehingga penyandang disabilitas seringkali juga dianggap kaum yang kurang beruntung sehingga setiap orang diminta untuk dapat melindungi hak kaum minioritas tersebut dan pendekatan sosial selalu menjadi jalur utama untuk memberikan perlindungan bagi kaum minoritas tersebut (Alia, Winda, Rizkisyabana, 2020).

Pemikiran yang negatif tentang penyandang disabilitas berasal dari pola pikir masyarakat yang didominasi oleh konsep normalitas. Melalui sejarah telah membuktikan bahwa banyak orang akan memandang aneh dan tidak normal terhadap orang yang memiliki kondisi fisik atau mental yang berbeda dengan orang normal pada umumnya (Dini Widinarshi, 2019).

Mengenai pemenuhan hak bekerja bagi penyandang disabilitas merupakan masalah yang cukup serius (Rozali, 2017). Mendapatkan pekerjaan merupakan kebutuhan yang vital bagi penyandang disabilitas karena banyak penyandang disabilitas adalah pengangguran dan sering dikucilkan secara sosial (Susiana, Wardah, 2019).

Realita menunjukkan bahwa masih banyak penyandang disabilitas 
yang belum terpenuhi aksesibilitasnya untuk bekerja. Bahkan, diskriminasi dan pembedabedaan perlakuan masih terus terjadi (Anisa, 2019).

Pada bagian perusahaan, perusahan memiliki alasan umum tidak memperkerjakan penyandang disabilitas yaitu dikarenakan hal tersebut dapat menghambat proses produksi yang sudah ditentukan (Utami Dewi, 2015).

Pada pasal 53 : (1) Pemerintah, Pemerintah Daerah, Badan Usaha Milik Negara,dan Badan Usaha Milik Daerah wajib mempekerjakan paling sedikit $2 \%$ (dua persen) Penyandang Disabilitas dari jumlah pegawai atau pekerja; (2) Perusahaan swasta wajib mempekerjakan paling sedikit 1\% (satupersen) Penyandang Disabilitas dari jumlah pegawai atau pekerja.

Jika dibandingkan kondisi pekerja penyandang disabilitas sebelum dengan sesudah munculnya Undang-Undang Nomor 8 Tahun 2016 Tentang Penyandang Disabilitas, kondisi penyandang disabilitas dapat dikatakan sudah mulai mengalami peningkatan/perbaikan. Berdasarkan data sebelumnya, dapat dilihat bahwa adanya peningkatan penyerapan tenaga kerja penyandang disabilitas di sektor formal dari tahun 2017 hingga 2019. Hal positif yang dapat dipertahankan dan harus ditingkatkan kerena jumlah penyandang disabilitas berdasarkan Badan Pusat Statistik (BPS) Februari 2019 tercatat jumlah penduduk usia kerja penyandang disabilitas sebesar 20,9 juta orang. Dari angka tersebut, angkatan kerja terdata sebesar 10,19 juta dan yang bekerja 9,91 juta orang. Sementara itu, jumlah pengangguran terbuka untuk penyandang disabilitas tercatat sebesar 289 ribu orang. Menteri Ketenagakerjaan (Menaker) Ida Fauziyah mengatakan, penelitian menunjukkan tingkat partisipasi tenaga kerja disabilitas lebih rendah dibandingkan TPAK pekerja non disabilitas, dan upahnya relatif lebih rendah. Ada pula tingkat pengangguran terbuka yang lebih tinggi pada penyandang disabilitas berat.

Jika dikaitkan dengan Teori Efektivitas Hukum Soerjono 
Soekanto, yang menjelaskan terdapat

5 (lima) faktor yang dapat dijadikan acuan dalam menentukan efektivitas hukum dalam penerapannya yaitu (1) subtansi hukum yaitu subtansi dalam peraturan undang-undang; penegak hukum yaitu pihak-pihak yang berwenang dalam menegakan hukum; (3) masyarakat yaitu mereka yang memiliki sifat taat terhadap hukum; (4) kebudayaan yaitu hukum harus dapat mencerminkan kebudayaan yang hidup di Indonesia (Soerjono Soekanto 2007). Berikut adalah hasil analisis nya yaitu:

a) Faktor Subtansi Hukum: Indonesia telah mempunyai perangkat hukum dalam melakukan penjaminan hak bekerja bagi penyandang diabilitas yaitu pada UndangUndang Nomor 8 Tahun 2016 tentang penyandang disabilitas. Bahkan dalam pasal 53 (1) menyatakan bahwa Pemerintah, Pemerintah Daerah, Badan Usaha Milik Negara,dan Badan Usaha Milik Daerah wajib mempekerjakan paling sedikit 2\% (dua persen) Penyandang Disabilitas dari jumlah pegawai atau pekerja. Pasal 53

Perusahaan swasta wajib mempekerjakan paling sedikit $1 \%$ (satu persen) Penyandang Disabilitas dari jumlah pegawai atau pekerja. Hal ini merupakan langkah baik dalam mendukung terpenuhinya hak bekerja bagi penyandang disabilitas. Namun, dalam undang-undang ini tidak mengatur tentang adanya sanksi bagi Pemerintah, Pemerintah Daerah, Badan Usaha Milik Negara (BUMN), dan Badan Usaha Milik Daerah (BUMD) dan perusahaan swasta jika tidak melakukan amanat pasal 53 (1) dan (2) tersebut.

b) Faktor Penegak hukum: yang dimaksud oleh penegak hukum yaitu pihak-pihak yang berwenang dalam menegakan hukum. Dalam hal ini, pihak yang berperan dalam memenuhi hak bekerja bagi penyandang disabilitas yaitu Kementerian Ketenagakerjaan, Kementerian BUMN, Pemerintah Daerah, BUMN, dan BUMD dan perusahaan swasta. Berdasarkan hasil penelitian, kementerian 
ketenagakerjaan dan kementerian BUMN sudah bekerja dengan baik dengan saling berkoordinasi dan membuat MoU untuk meningkatkan jumlah tenaga kerja penyandang disabilitas. Namun, perlu adanya kesadaran juga dari pihak perusahaan swasta dalam memahami adanya kewajiban sebagaimana yang diatur pada pasal 52 (2) tersebut karena tingkat penyerapan tenaga kerja penyandang disabilitas di sektor swasta masih tergolong kecil.

c) Masyarakat : yang dimaksud dengan masyarakat disini adalah mereka yang memiliki sifat taat terhadap hukum. Masyarakat dalam penelitian ini adalah tenaga kerja penyandang disabilitas. Berdasarkan penelitian terdahulu, ditemukan bahwa alasan rendahnya persentase partisipasi penyandang disabilitas dalam dunia kerja disebabkan oleh berbagai hal. Beberapa faktor penyebab yaitu adanya kesenjangan keterampilan antara penyandang disabilitas dengan pekraj normal, masih rendahnya tingkat pendidikan penyandang disabilitas, dan masih adanya sikap diskriminatif masyarakat terhadap penyandang disabilitas (Geminastiti, 2018). Oleh sebab itu, kementerian BUMN melaksanakan pelatihan kerja untuk penyandang disabilitas sebagai upaya dalam membekali keterlampilan tenaga kerja penyandang disabilitas.

d) Kebudayaan : yang dimaksud dengan kebudayaan yaitu hukum harus dapat mencerminkan kebudayaan yang hidup di Indonesia. Dalam hal ini, kebudayaan yang dimaksud adalah kebudayaan yang membawa pengaruh kepada tingkat penyerapan tenaga kerja penyandang disabilitas.

Perusahaan masih berkehendak untuk mencari sumber daya manusia yang berkualitas tanpa kecacatan. Hal ini terlihat dari proses seleksi yang dijalankan baik itu di perusahaan swasta, BUMD, BUMN 
dan organisasi pemerintahan. Persyaratan yang digunakan dalam proses seleksi masih banyak yang mensyaratkan kesempurnaan jasmani dan mental dari para pelamar. Menurut Noemijati (2008 : 561), permasalahan yang sering dihadapi organisasi adalah kenyataan bias ketika proses tes untuk seleksi dilaksanakan. Kusumardani S., Diah (2005 : 76) mengidentifikasi bahwa mengelola diversitas tenaga kerja dengan jalan menghormati karyawan merupakan salah satu tantangan yang dihadapi oleh perusahaan saat ini. Tenaga kerja dengan berbeda karakteristik akan muncul pula tantangan terkait cara bertindak dan berkomunikasi yang berbeda (Kusumardani S., Diah, 2005: 84).

\section{Simpulan}

SDGs merupakan salah satu langkah negara di dunia dalam melakukan pembangunan berkelanjutan. Hal ini dilaksanakan di negara maju dan negara berkembang. Indonesia merupakan negara yang juga berkomitmen dalam mewujudkan SDGs. Salah satu tujuan SDGs adalah penyediaan lapangan pekerjaan untuk semua pihak dan prinsip yang dipegang oleh SDGs adalah "no one leave behind". Hal ini semakin memberikan tantangan bagi Indonesia dalam menyediakan lapangan kerja untuk semua tanpa terkecuali termasuk kaum penyandang disabilitas. Indonesia sendiri telah memiliki regulasi dalam menjamin terpenuhinya hak bekerja bagi penyandang disabilitas yaitu di Undang-Undang Nomor 8 Tahun 2016 Tentang Penyandang Disabilitas. Namun, jika diukur dengan Teori Efektivitas Hukum Soerjono Soekanto yang melihat dari beberapa faktor yaitu subtansi hukum, penegak hukum, masyarakat dan kebudayaan hukum, maka terdapat beberapa kelemahan pada faktor hukum, masyarakat dan kebudayaan hukum. Oleh sebab itu, terdapat beberapa rekomendasi dalam penelitian ini yaitu: 1) perlu adanya koordinasi kerja antar kementerian yang lebih komprehensif lagi, khususnya antara kementerian ketenagakerjaan dan kementerian BUMN; 2) perlu adanya ratifikasi pada Undang-Undang 
Nomor 8 Tahun 2016 Tentang Penyandang Disabilitas terkait pemberiaan sanksi bagi pihak yang tidak memberikan kuota/kesempatan kerja bagi penyandang disabilitas sebagaimana yang diatur pada pasal 53 (1) dan (2); 3) Meningkatkan pelatihan kerja/ pembekalan kerja bagi penyandang disabilitas agar mereka juga siap bersaing di dunia kerja; 4) Perlu adanya revisi atau perubahan rekrutmen pekerja agar penyandang disabilitas juga memiliki peluang untuk dapat diterima bekerja di sektor swasta.

\section{Daftar Pustaka}

\section{Buku}

Badan Pusat Statistik,2014, Kajian Indikator Lintas Sektor:Kajian Indikator Sustainable Development Goals (SDGs), Jakarta: Badan Pusat Statistik.

Soekanto, Soekanto. 2007, FaktorFaktor yang Mempengaruhi Penegakan Hukum. Jakarta: Penerbit PT. Raja Grafindo Persada

Soekanto, Soerjono. 2009, Pengantar Penelitian Hukum, 3rd ed. Jakarta: Restu Agung.

\section{Jurnal}

Aji, Abdul Latief Danu, Tiyas Nur Haryani, 2017. "Diversitas dalam Dunia Kerja: Peluang dan Tantangan bagi Disabilitas", Jurnal Spirit Publik Volume 12, Nomor 2, Oktober.

Anisa, 2019, "Kelompok Difabel Dan Kesempatan Kerja: Penanggulangan

Diskriminasi Di Dunia Kerja Dalam Perspektif Pekerjaan Sosial", Jurnal Pengembangan Masyarakat Islam, Volume 5 Nomor 2, Juli-Desember.

Dewi, Utami. 2015, "Implementasi Kebijakan Kuota bagi Penyandang Disabilitas untuk mendapatkan Pekerjaan Di Kota Yogyakarta”, Jurnal Natapraja, Volume 3, Nomor 2.

.Hamidi, Jazim. 2016, "Perlindungan Hukum terhadap Disabilitas dalam Memenuhi Hak Mendapatkan Pendidikan dan Pekerjaan", JH Ius Quia Iustum, Volume 23, Issue 4, Oktober.

Ishartono, Santoso Tri Raharjo, "Sustainable Development Goals (SDGs) Dan Pengentasan Kemiskinan", Social Work Journal, Volume 6 Nomor 2.

Pupin Astuti, Nur Hanifah JS, Aulia Nur Aziza, Nurfadilah Alwan, Fahira, 2020. 
"Gambaran Pengetahuan

Dan Sikap Mahasiswa Universitas Hasanuddin Tentang Perwujudan Sustainable Development Goals (SDGs) 2030 Di Indonesia", Jurnal Abdi, Vol.2 No.1 Januari.

Purinami, A Geminastiti, Nurliana Cipta Apsari, Nandang Mulyana. 2018, "Penyandang Disabilitas Dalam Dunia Kerja", Jurnal Pekerjaan Sosial, Volume 1 Nomor 3, Desember.

Rozali, Norhasyiki, Shuhairimi, Abdullah, Ishak, Siti Intan Diyana, Azmi, Alia Ashrani, \&Akmar,Nurul Husna. 2017. "Challenges faced By People with Disability for Getting Jobs: Entrepreneurship Solution for Unemployment". International Journal of Academic Research in Business and Social Science, Vol.7, No.3.

Susiana, Wardah. 2019, "Pemenuhan Hak Penyandang Disabilitas Dalam Mendapatkan Pekerjaan di BUMN", Jurnal Law Reform, Volume 15, Nomor 2.

Tan, Winsherly. 2020, "Pemenuhan Hak Pendidikan Anak Jalanan Di Kota Batam: Tantangan Dalam Mewujudkan Sustainable Development Goals (SDGs)", Jurnal Supremasi
Hukum, Vol. 29, No.1, Januari.

Wahyuningsih, 2017. "Millenium Develompent goals (MDGs) Dan Sustainable Development Goals (SDGs) Dalam Kesejahteraan Sosial", Jurnal Bisnis dan Manajemen Vol. 11, No. 3 September 2017.

Widinarsih, Dini. 2019, "Penyandang Disabilitas di Indonesia: Perkembangan Istilah dan Definisi”, Jurnal Ilmu Kesejahteraan Sosial, Jilid 20, Nomor 2, Oktober.

Widjaja, Alia Harumdani, Winda Wijayanti, Rizkisyabana Yulistyaputri. 2020, "Perlindungan Hak Penyandang Disabilitas dalam Memperoleh Pekerjaan dan Penghidupan yang Layak bagi Kemanusiaan", Jurnal Konstitusi, Volume 11 Nomor 1, Maret.

\section{Peraturan Perundang-undangan}

Undang-Undang Dasar 1945

Undang-Undang Nomor 8 Tahun 2016 Tentang Penyandang Disabilitas

Website
BUMN, "Menteri BUMN dan
Menteri Ketenagakerjaan
Tandatangani MoU",
https://bumn.go.id/media/pr
ess-conference/menteri-
bumn-dan-menteri -


ketenagakerjaan-
tandatangani-mou-x5,

diakses 28 Oktober 2020

Infid, "Perkembangan Pelaksanaan

Sustainable Development

Goals (SDGs) di Indonesia”, https://www.sdg2030indone

sia.org/an-

component/media/upload-

book/Briefing paper_No 1

SDGS -2016-

Meila Sekar.pdf, diakses 28

Oktober 2020.

Republika, "Sepanjang 2020, BUMN

Sudah Serap 178 Tenaga

Kerja Difabel"

https://republika.co.id/berita

/qduzp1370/sepanjang-

2020-bumn-sudah-serap-

178-tenaga-kerja-difabel,

diakses 27 Oktober 2020.

Tempo, "Baru 1 Persen Teman Disabilitas yang Bekerja di Sektor Formal", https://difabel.tempo.co/read /1143835/baru-1-persenteman-disabilitas-yangbekerja-di-sektorformal/full\&view $=$ ok, diakses 27 Oktober 2020 